\title{
An opinion on the phenomenon of "coercion" in school management in the context of traditional Chinese culture: principles, essence and criticism
}

\section{Xu Bo}

\begin{abstract}
Research on workplace bullying in Western academic circles has formed a relatively complete academic system which in China is particularly insufficient. However, "coercion", a specific phenomenon of workplace bullying, still exists in many forms and in many aspects of Chinese school management. From the perspective of the historical context of Chinese traditional culture, it contains some basic elements such as the intimidators, the coerced persons, the specific content, the methods and the environment. These factors and their interactions are important clues to the analyses of their mechanisms. From the perspective of "the flow and distribution of social resources", "the operation process of public power" and so on, coercion is very harmful because of its pursuit of "efficiency standards", adhering to the concepts of "sex-oriented evil", "spiritual violence" and so on. Therefore, in order to continuously improve the quality of school management, we should seek some measures to realize a Chinese-characteristic school management system.
\end{abstract}

Key words: workplace bullying; school management; management style; coercion; people-oriented management. 


\section{Abstrakt}

Výzkum šikany na pracovišti v západních akademických kruzích vytvořil relativně kompletní akademický systém, který je v Číně obzvláště nedostatečný. „Vyhrožování a donucování", specifický jev šikany na pracovišti, však stále existuje v mnoha podobách a v mnoha aspektech čínského rízení škol. Z pohledu historického kontextu čínské tradiční kultury obsahuje některé základní prvky, jako jsou šikanéři, šikanované osoby, specifický obsah, metody a prostředí. Tyto faktory a jejich interakce jsou důležitými vodítky pro analýzu těchto mechanismů. Z pohledu „toku a distribuce sociálních zdrojü“, ,"fungování procesu veřejné moci“ atd. je donucování velmi škodlivé, protože sleduje "standardy účinnosti" a dodržuje koncepty "genderově orientovaného zla“" ${ }_{\text {" }}$ duchovního násilí" atd. Abychom tak neustále zlepšovali kvalitu ř́zení škol, měli bychom zavést některá opatření do čínského systému řízení školy, který je charakteristický.

Klíčová slova: šikana na pracovišti; vedení školy; styl řizení; zastrašování a donucování; řízení orientované na lidi

\section{Introduction}

Workplace bullying is also called work environment bullying. In the late 1970s and early 1980s, Nordic scholars first began to study the problem of "bullying". It was not until the 1990s that scholars began to conduct systematic research on this issue, then the problem of bullying in the workplace was generally considered by multi-country scholars (Wang Hong, 2014). Because of the differences between the elements and the focus of the bullying, different scholars have different definitions of workplace bullying. At present, the definition of Gary Namie and others is the most representative. They defined workplace bullying as: a variety of torture that has a hostile perpetrator, it is intentional and repeated on the victim based on the control of selfish desires (Namie, 1999). Scholars generally agree that bullying in the workplace has the following characteristics: it is an intentional act, and those who are bullied can feel the hostility of the bully operator; the two bullying sides have unequal power in many aspects; it will cause direct or indirect injuries to the bullied on the physical, psychological, emotional or other aspects; it is a continuous and frequent bad behaviour; it is one of the aggressive behaviours, and the negative effect on the individual and the organization is far greater than positive influences (Feng Weilin, 2016). Coyne, Leymann, Einarsen and other scholars have studied the antecedents and outcome variables of bullying in the workplace, factors such as the individual, organization, leader and so on are analyzed (Coyne, 2000; Leymann, 1996; Einarsen, 2005), a corresponding behaviour measurement scale is prepared to evaluate the specific situation of the bullying behaviours (Einarsen, 1997). 
Current research on workplace bullying is mainly carried out in Europe and the United States. In contrast, Chinese research in this field is lagging behind, and is mainly focused on current situations, causes and preventative measures between students in schools (Zhou Hongjun, Liu Haiming, Wang Yunhao,2019; Zhao Tingting, 2018; Ji Yantin, Shi Changjun, 2017). However, there is a lack of research on bullying between employees in the workplace, or between leaders and employees. Taking relevant research included in China's largest database of knowledge and information achievements as an example, since 1980s, there are only 54 periodical and degree papers on related topics such as "workplace bullying", "work environment bullying" etc. Most of this research is based on Western theories, and only introduces relevant Western research results (Yu Luling, 2014; Chen Weina, 2009), discuss the influence on the related psychological factors of employees (Nie Guanghui, Li Yongxing, Tang Zhenghua, 2011; Jiang Jiang, Dong Jiao, Wang Rong, 2012; Du Hengbo, Zhu Qianlin, Xu Yanfeng, 2016). Exploration of the research and development in the field of China (Xiao Yonping, Peng Shuo, 2014; Ren Huiyuan, 2019) or different understanding of the relevant issues between China and the West (Fu Meiyun, Ma Huawei, Le Guoan, 2014).

Generally speaking, research on workplace bullying in China and the West mainly focuses on the working environment of enterprises, companies and so on, but the research on bullying in the field of school management is relatively limited. So far, there are only three public articles about bullying between school administrators and sub-managers or teachers in mainland China. Among them, Zhao Pengjuan studied bullying of teachers in weak subjects in primary and secondary schools in the form of a questionnaire survey (Zhao Pengjuan, 2015); through the collection and collation of literature, Qin Lijun introduced some measures taken by the United States, Britain, Germany, Ireland and other countries to protect teachers from cyberbullying and the related insights for China (Tan Lijun, 2017); Zhao Fang, on the other hand, focused on the specific situation of British teachers' anti-cyber bullying law (Zhao Fang, 2015).

At the same time, in the context of Chinese language, "bullying" and "coercion" have similar meanings, so "coercion" can be regarded as a special form of "bullying". But differences in their semantics are also apparent, "coercion" more greatly emphasizes the meaning of "threat" and "force" in the process of "bullying". In order to further enrich Chinese research in this field, the phenomena of "coercion" in the field of school management is discussed based the background of traditional Chinese cultures, especially the typical workplace cultures, and preliminary deconstructing strategies are put forward. 


\section{The connotation and significance of school management style}

The connotation of school management style is extremely rich. For example, from the perspective of traditional behaviour management, this refers to the behaviour management characteristics of school managers in the process of management; from the perspective of history and culture, it refers to the behaviour, style or manner embodied by school managers under the direction and guidance of the corresponding organizational culture and management views; from the point of view of the management process, it refers to the links of planning, organization, coordination, control and so on, in the course of school administrators performing their management functions (Liang Yuhua, Zhang Xiangsheng, 2016).

Management styles have some profound impacts on the organizational changes, innovations, atmosphere, teacher enthusiasm and organizational commitments. Broadly, styles of school management can be divided into three basic types: laissez-faire, democratic and authoritarian, each type can also be divided into several subtypes (Zhang Ying, 2012). The phenomenon of "coercion" is common in authoritarian management style. School management style can reflect workplace culture and even the traditional culture of a country or region to a certain extent. Because traditional Chinese workplace culture emphasizes the concepts of familyism, human relations, authoritarianism, hierarchy, moderation and social orientation, it can affect the cognition and coping style towards coercion in individuals and in a school as a collective (Guo Jing etc., 2015), the authority-type management style is more likely to be adopted. Therefore, the phenomenon of "coercion" is relatively more common in traditional Chinese school management styles.

\section{The "coercion" approach: connotations and mechanisms of the coercive phenomenon in Chinese school management}

McGregor once stated that managers could not succeed in forcing people to work for their goals, the ideas that people work simply because of they are threatened, intimidated or because of paternalistic hypocrisy coercion will soon disappear (Klock \& Gold Smith, 2004). However, to this day, from the concept of management to the system design, and then to the specific management practice, "coercion" still lurks in many areas of school management in many forms and restricts the improvement of the levels of school management. Traditional culture of China is of good quality, such as self- 
improvement, peace and moderation, and being people-oriented (Sheng Shangwu, Yuanyue, 2012), and also has the remarkable characteristics of conformity, fixed thinking, emphasis on groups over individuals, worship of authority, etc. (Yang Lijun,2004). More importantly, we should resist the negative effects of "coercion" in school management. Therefore, on the basis of analyzing its functional principle, it is of great significance for school managers to optimize their management style and improve their management quality by critically exploring its essence and reasons, and then constructing a more reasonable management mechanism.

\subsection{The connotation of "coercion" in school management}

"Coercion" is a certain form of threat or force (Institute of language, Chinese Academy of Social Sciences, 2012). Its essence is that based on a variety of purposes, coercive people adopt behaviours such as threatening, forcing and even non- humanitarianism to persuade others towards their will, it is a special form of bullying. "Coercion" in school management mainly refers to the administrators either alone or in groups using authoritarian preaching, regulating, or reprimanding to one or several members in the school by their personality, status, power, money and other personal or social resources through rules, languages, actions, etc. in management links such as planning, organization and coordination. Those who are coerced are often ordinary teachers or administrators with lower positions.

From different viewpoints, "coercion" in school management can be divided into different categories. From the point of view of the vehicle, it can be divided into language coercion, expression coercion, action coercion, thought coercion, object coercion etc; from consciousness, it can be divided into intentional coercion, unintentional coercion; there are direct coercions and indirect coercions; for visibility, it can be divided into explicit stress and recessive coercion; it can be divided into individual coercion and group coercion; in terms of interactions, there are one-way and two-way coercions.

\subsection{The operational mechanism of "coercion" in school management}

In coercive school management, although the content and expression of the "coercion" can differ, any specific coercion includes the intimidator, the coerced person, the specific content, the method and the environment. The operational mechanism of coercive management effectiveness involves these basic factors and their interactive relationships, that is, the final results of the coercion are dependent on the elements and their complex interactions. The specific mechanism of action is shown in the following figure: 
Figure 1

Influencing factors of coercion effectiveness and their interactive relations

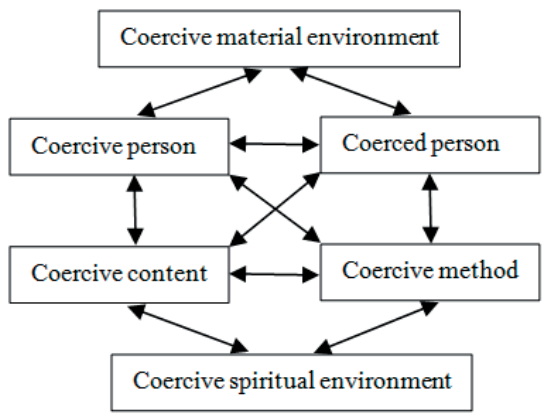

As is shown in the figure above, among the influencing effective factors, the "coercive person" is the initiator and promoter of the school's coercive management. In an actual management situation, it is often the higher level school managers who have the higher power and who grasps the collective high quality social resources; the "coerced person" is the recipient of the coercion, mainly the secondary manager or the ordinary teacher; the "coercive content" is the main aspect of the exchange between the two sides, it refers not only to the work itself, but also to a variety of social resources of mutual concern. The "coercive method" is the path, procedure or way of coercive operation; the "coercive material environment" is independent of human consciousness, it is the objective material condition of school operation and management, regulation and distribution modes. The "coercive spiritual environment ${ }^{\prime \prime \prime}$ mainly refers to the spiritual and conscious situation and conditions composed of the cultural atmosphere, organizational mechanism, and day to day practices.

As we can see from the figure above, the factors affecting the effectiveness of coercive management are not only relatively independent, but also related to each other and interact with each other. Any coercion factor or interaction between factors will affect the total effectiveness of the coercion. In the practice of school management, the premise or basic assumption of the smooth operations of "coercion" are often as follows: as the subject of coercive implementation, the school managers have mastered many social resources inside and outside the team, such as funds, power, the right to speak of social morality and so on. School managers are superior to ordinary teachers or secondary managers as the occupant of social resources in terms of quantity or quality. School managers have greater authority in the allocation of social resources in the team and enjoy the right of priority choice or decision-making; the coerced persons are interested in such social resources and seek to obtain them, and actively or passively accepts their acquisitions as the coerced. In the current situation, it is impossible or 
more difficult for the coerced persons to obtain such social resources actively through other approaches.

So even from an analysis of the theory itself, there are also many difficulties in the Chinese coercive management style in order to give full play to the "effectiveness" desired by the coercers, because any of the above prerequisites or assumptions are not satisfied in the specific situation, the role of coercion cannot be played or limited. In addition, existing research shows that traditional ethical culture may profoundly influence the value orientations and behaviours of the subjects. The more attention is paid to humane care, and a fair and just environment, the less there are bullying behaviors in the workplace, and the less the corresponding coercion phenomena; the more attention is paid to short term and economic benefits, the more common the problem of bullying in the workplace, and the more the corresponding coercion (Power, 2013).

\section{3 "Coercion" and "counter coercion"}

In a coercive school management situation, managers have a relatively superior social level, those who are coerced are often secondary managers or ordinary teachers with a lower social class. In the traditional workplace environment of China, the school management system is often dominated by the hierarchical system, this kind of social grade difference is an important prerequisite and basic carrier for the emergence and operation of "coercion". But as the saying goes "where there is oppression, there is resistance", at the same time as the coercers carry out "coercion", the coerced persons often carry out "anti-coercion". They will be against all kinds of threats or forcing from the coercers directly or indirectly. Their resistance presents in many forms, including direct and indirect; positive and negative; individual and group; immediate and delayed; high and low frequency; local and comprehensive. In the real school organization and management, the most common form of anti-coercion is the implicit resistance of "agree in words but not in mind" or procrastination or even refusal after taking orders in person. Typical Chinese workplace culture emphasizes the traditional patriarchal thought and the application of politeness principles such as respect and humility and attaches importance to the identity level and a strict interpersonal hierarchy (Liang Jing, 2017). Therefore, many kinds of indirect, negative, delayed or hidden "resistance" arises more easily. The cohesion, vitality, time, energy and willingness of a school's organizational team are often wiped away in this "tacit resistance". Eventually, the organization moves towards collective internal friction and decline.

In addition, "coercion" is interchangeable, on the one hand, school managers use power and public opinion to "threaten" ordinary teachers or secondary managers directly or indirectly through their controllable social resources; on the other hand, the coerced members can also use their own social relations, knowledge, personality, things that managers are interested or afraid to reverse coercing superior managers. When the 
stress of one party reaches a certain amount or to a certain extent, the other party is bound to carry out anti-stress behaviours in many forms. Either party's sense of stress and the corresponding feedback he takes in a coerced relationship depends on the person, the matter, or the situation. These factors and their interaction ultimately affect the results of coercion, and then affect the quality of school management and the development of organizational teams.

\section{The thinking behind "coercion": the essence and criticism of the phenomenon of "coercion" in Chinese school management}

\subsection{The essence of coercive management}

The phenomenon of "coercion" in Chinese school management have a complex mechanism, in addition to that influence of its own constitution factors and their interactions, it is also restricted by historical traditions, social development levels and other factors, so it can be analysed from many angles. For example, in terms of flow and distribution of social resources, in the typical Chinese coercive school management situation, it seems to be the interaction between managers and managers, managers and teachers, teachers and teachers under the established school organization mechanisms. In fact, it is also the exchanges and flow of a variety of "social resources" or "interests" in many forms and at many levels. The most common distributions are top-down hierarchical flow: the superior managers of the coercers control a wide range of resources and benefits and their distribution rights, as coerced persons, secondary managers or teachers directly or indirectly accept multiple forms of coercion from superior managers. In exchange, a variety of social resources and interests are distributed from the coercers to the coerced. The similar operation processes of coercion are also the regulation, distribution and even competition of social resources under the cover of all kinds of grand "shyness" or "social mask" - a large group of people at many different levels in schools, engage in essentially "inhuman" transactions through the external form of the existence of people and school organizations.

From an operational point of view of public power, in China's typical situation of coercive management, school managers often have a "master" mentality when they coerce ordinary teachers or secondary managers. That is, subconsciously they think of themselves as the "master" of the school, while others are tame or stubborn servants. However, ordinary teachers or secondary managers are influenced by the concepts of "belittling himself and respecting others", "keeping a low profile", "safeguarding the overall situation" and "be wise for personal survival" in the traditional workplace culture 
(Bao Xianzhi, 2014), always be patient and accepting. Since the school managers are the "master" of others, it is very easy to give birth to a kind of mentality and impulse of "do whatever I want". This mentality will be even more evident if other managers or teachers fail to suppress it in a variety of ways. In essence, this mentality is to "privatize" the organized public power. In fact, the current power of managers is given by their organization, there is a great deal of contingency for managers personally, managers only exercise the corresponding powers on behalf of the organization as a whole. In the process of "privatization" of public power, genuine public rights are diluted by private rights and are gradually marginalized. The personal will of managers is gradually "public" and "popular". However, it is far from the true popular will, it is just a personal idea, a very impure sense of will, a selfish desire packaged with a coat of great personal colour and even no reasonable meaning.

\subsection{Causes of coercive management}

Many scholars have analysed the causes of bullying in the workplace from the perspectives of occupational health psychology and organizational behaviour. They thought the main reasons include abuse of management power, characteristics of the organization, work organization and design defects, uneven power, sex, salary status, injustice, pressure, frustration etc. In a traditional Chinese school management environment, the effectiveness of "coercion" is affected by these factors themselves that the environment, the perpetrator, the recipient, the content and method of coercion, etc and their interaction relationship. At the same time, an analysis of the causes of stress can also start from these dimensions. In a wide range of coercive managements, the motivation or reasons for school managers to carry out intimidation are very complex. Such as the strong personality characteristics of managers, managers lacking advanced management concepts or skills, an unconnected team of teachers, the traditional atmosphere and management style of the school, punishment of "poor skills", "abuse public power to retaliate against a personal enemy" style of venting etc. Taking personality characteristics of school managers as an example, if they have stronger control and power desire, are often self-centred, paranoid, and under other conditions are unchanged or similar, they are more likely to see the world and others as competitors or tools available to them. When subordinates' feedback run counter to their personality or ideas, they tend to manage them in a variety of ways through threat or force.

\subsection{Criticism of coercive management}

Through an analysis of the connotations, mechanisms, causes and essence of "coercion" in China's typical school management, it is not difficult to find that there are obvious drawbacks in this style of management. In order to improve the management level 
and improve the quality of school management, it is necessary for us to criticize it objectively and rationally.

From a philosophical point of view, Chinese coercive management often pursues technical rationality and follows the logic of efficiency. It is emphasized that the environment should be controlled by rule-based and efficient behaviour, and "control" is its core. Managers often ignore the subjectivity of secondary managers and teachers and pay more attention to their instrumental value. The latter's interests, needs, emotions, values, etc., are often obscured by routine tasks or leadership authority. But after all, those who are coerced are individuals with blood, feelings, thoughts, emotions, and great subjective initiatives, rather than "domesticated animals". Therefore, it is difficult and unreasonable to manage them in a forced and threatening manner.

From the point of view of human nature, in the context of Chinese coercive school management, managers tend to hold the view of "sex-oriented evil", that is to say, it is believed that the natural nature of human beings is "evil", people are born to avoid and hate work, only by means of supervision, control, coercion or punishment can they be forced to achieve the school goals. So, they tend to use strict rules, strict supervision mechanisms or various utilitarian social resources to coerce subordinates in their management style. However, even from the point of the theory of human nature itself, as Rousseau said, "No one has a natural right to control his kind", "God gives everyone equal rights" (Jin Binghua et al., 2001). Therefore, coercive management is inhumane and anti-human, the pursuit and acquisition of freedom, equality and fairness are not only the nature of human beings, but also their basic rights. From the view of the actual utility of management, "sexual evil" also makes it difficult to consider the comprehensiveness and complexity of human nature. People often do not simply live for utilitarian interests, and it is difficult to really succumb to all kinds of intimidation. Therefore, coercive management based on the theory of sexual evil is difficult to implement effectively in the school management for the long term because of its neglect of the real and rich human nature.

From the view of a spiritual and moral dimension of management, Chinese coercive management is also a kind of "mental violence'". It ignores the spiritual characteristics that good school management ultimately depends on will consciousness and moral self-discipline. It seriously suppresses the creativity and initiative of the majority of teachers and ignores the promotion of their interests, needs, values and spiritual realm, and is also not conducive to their moral generation and the self-construction of the meaningful world in their work. Therefore, it can not only stimulate the enthusiasm of teachers, but also affects the interpersonal relationship and working atmosphere of the school organization. It not only hinders the significance of school education management, but also seriously affects the improvement of education quality. In the end, it is impossible to train talents who are mentally independent and develop in an all-round way. 
From the point of view of abandoning and sublimating Chinese traditional culture, a typical Chinese coercion-style school management mainly inherits some of the inertia factors in the traditional Chinese culture. For example: hierarchical ethics, patriarchal consciousness, collective standard, etiquette (Feng Hui, 2010). But as the world's only long-standing culture with no interruption of development, it also has some fine characters, such as "the unity of heaven and man", "self-improvement", "commitment to patriotism", "be honest with others", "diligence and thrift", "being careful and loving alone" and so on (Gu Mingyuan, 2004). Obviously, coercive management has chosen the wrong path in the sublimation of history.

While revealing the disadvantages of Chinese coercive school management, we also need to realize that in any real school management situation, from the point of view of ordinary teachers or low-level managers, the less stress they bear, the better, and if there is no stress then so much the better. But when looking at school management in specific situations from a sociological perspective, we will find that some form of constraint, requirement or restriction is both inevitable and indispensable. Even in some special situations, the approach of threat and force is more conducive to the development of teachers and to the maintenance of the overall and long-term interests of the school. But even in "extraordinary times" or "extraordinary circumstances" and coercive means are used for a reasonable and moral purpose, it should also be made as far as possible that "strategic coercive; tactically, but not coerced or less coerced. Strategic enforcement, tactical, but not mandatory or less mandatory" (Wang Xiaochun, 2011). Therefore, on the whole, we should advocate the management mode and style of "non-threat" and "non-forced" in school, so as to create a safe and relaxed psychological atmosphere for teachers. Moreover, any coercive school management can almost be replaced by non-coerced and humanized strategies.

\section{Deconstructing coercion: Chinese-characteristics and humanism school management measures of "for the sake of the collective and self-achievement"}

Based on the analysis and criticism of the principle and essence of "coercion", in order to improve the quality in Chinese school management and get out of the misunderstanding of "intimidation", we should focus on the construction of a people-oriented Chinese-characteristics school management system of "for the sake of the collective and self-achievement". The idea of "human-oriented management" rose in the 1950s and 1960s and penetrated the field of education immediately. It emphasizes being "people-oriented", in addition to the instrumental value, it attaches more importance to the subject value of human beings and places people themselves at the core of de- 
velopment. In educational management, humanistic school managements emphasize taking the development of people as the core, the understanding of people as the link, and the respect for people as the basis. The focus includes publicizing people's personality, arousing people's vitality, developing people's potential, create an upward and promising, sincere cooperation, equal unity, positive and healthy working atmosphere, to make the school management realize self-discipline, self-realization, self-awakening realm development (Chen Shiting, 2015).

\section{1 "The collective" and "the individual": correctly understanding and dealing with the relationship between the two factors}

The "collective" may refer to a specific teaching team or school, which can be widely applied to a wide range of educational organizations or more macro educational ideals; the "individual" in school management, mainly refers to the specific managers or individuals. The collective and the individual are antagonistic and interdependent: the "collective" is a combination of many "individuals"; "individuals" are the "individual" that divides from the "collective", the two contain each other and transform each other. Therefore, in the school management of the human-oriented, it emphasizes the understanding and respect for the life value of much "individual", and really treats the person as a person, and relies on the human, makes human as the starting and the landing point. At the same time we should unify the development of the "individual" in the process of realizing the meaning of the "collective", in order to cultivate excellent talents with spiritual independence, both virtue and talent, and the development of physical and mental health, even changing social customs and bring up the sense of responsibility and demeanour of a better society. The two are mutual accomplishments and common developments.

In the process of dealing with the relationship between the "collective" and the "individual", both managers and ordinary teachers need to understand the relationship between "I need a career" and "a career needs me"." "I need a career" is mainly a kind of self-direction, meeting certain needs of one's own through the career and its development. These needs may be utilitarian or based on pure motivation; "career needs me" means that the development of any career needs builders and promoters. But the word "I" here mainly refers to "I as a collective or group". The career often does not need the specific you, I and he or she, because for the vast majority of the "individual", there is a strong alternative. Only if the personality and the profession is maintained, could the person who can promote the career development truly realize the leap from "I need the career" to "the career needs me". 


\section{2 "For the sake of the collective": to strengthen the organization construction of the school}

In order to realize the goals of education, making teaching and social services in schools better, it is necessary to strengthen the organizational construction of schools in the process of the construction of humanistic school management system. At a macro level, people-oriented ideas and the corresponding operation strategies should be implemented in each link of the construction of the school management mechanism. Organization mechanism and cultural mechanism should be implemented based on adhering to the management principles of democracy, subjectivity, development and creativity. At a micro level, resource allocation of the construction of the school organization should be optimized constantly, and the talent teams of management and teaching should be improved. The concept of knowing and employing people should be updated, people need to be placed in the right position, and the evaluation mechanism of talents should be optimized. Under the guidance of human-oriented thought, the school managers should strengthen emotional managements and cultivate a sense of belonging, identity and responsibility of the majority of teachers through the concepts and measures of "spiritual contract" and "community of destiny". They should focus on shifting attention from the simple utilitarianism of the student's examination scores or the self-evaluation, the prizes and the professional ranks and titles to the organized goals of the organization. In the process of strengthening the construction of the school organization, the following issues, presented below, are of particular concern.

The significance of "persons" and "affection" in school management: "persons" in school management should be seen in the sense of humans rather than as labour. That is, managers should take persons (subordinates) as the main bodies, respect their values and care for their interests. The "affection" should be a real "emotional feeling". It is a kind of affection to the subordinates, to the colleagues, the persons, the concern, the pleasure, the love. If there is neither real "person" nor "affection" in mind of the school administrators, the team will be in a state of mechanical development, and the operation of the organization will only be the uploading and issuing of orders, and eventually falls into a state of discord and distraction. Therefore, key to the success of school management is paying attention to, studying, confirming and respecting people, it is the centre and the foot of all the rest of work.

The condensing "spiritual temperament" of the team: if any team or school achieves sustainable development, professional technologies and spirits are indispensable. A person has an ideal of life, a team or a school should also have professional pursuit and career aspirations. Any school or organization must gradually condense a kind of "spiritual temperament" belongs to their own collective spiritual characteristics and atmosphere in the process of self-growth. Good team "spiritual temperament" has a pure movement, both and beyond the professional spiritual appeal. Under the influence 
and encouragement of such beliefs, team members can transcend all kinds of worldly temptations, meditated and pious for the growth and progress of students, for a better collective tomorrow and try their courage, work in silence, and move forward bravely. Otherwise a major factor, the prosperity of a school, will eventually be a mirage, effectively a flash in the pan. The upright and kind souls will be distorted and deformed, silence in depravity, and die out in silence.

Dealing with all kinds of "lesions" in the process of tissue development in time: in the process of development, any organization will produce a lot of negative energy. If not resolved timely, it will gradually form "lesions" of tissue development. Over time, they will deteriorate into "tipping points" and virtually consume a lot of energy and resources from the development of the organization. In the torment of all kinds of "chronic diseases" and "acute diseases", the organization gradually loses its vitality, and finally goes into a state of silence. Therefore, school managers should be good at finding all kinds of contradictions and conflicts hidden in the organization, channel all sorts of "grievances" timely, correct all kinds of fallacies and erroneous practices promptly. Only in this way, the operation of organization can achieve the upper pass, maintain the vitality and the correct development direction.

\section{3 "Achieving the individual": school administrators and teachers should constantly improve their self-cultivation}

In humanistic management of schools, the development of a school as the collective should also be realized through the growth and development of individual managers and teachers as individuals. Schools should actively promote personal development, at the same time, individuals should work hard to grow themselves. The key to selfgrowth lies in constantly strengthening self-cultivation of personality. Strive to make oneself a wise, rich, soft, strong and resolute person in the process of studying, absorbing and cultivating (Silv, Wen Ruoyu, 2015). On this basis, if other specific professional ideas and vocational skills have solid support, then one can really achieve. The process of improving self-personality cultivation, involves many aspects concrete, or abstract important content, such as:

Constantly improving one's own realm of life. If a person only looks at normal society and life from his own perspective, it is inevitable they produce a lot of misplaced judgment. The higher realm of life is the facade and transformation of "evil", contempt and tolerance for "shame", sympathy and support for "weakness", yearning for and obeying "good". An aesthetic outlook on life that is open-minded, tolerant, calm and transcendent not only means the promotion of human spirit, but also shows a person's love and understanding of life. He not only understands and loves himself, but also 
understands and loves others, which is the spiritual source of happiness in life (Wang Kunqing, Yue Wei, 2011).

Adjusting one's work mentality. If the basic atmosphere of work is based on "fame, profit, power, money, excellent evaluation, award evaluation, professional title evaluation", then the core living conditions of struggling people are similar. At this time, the external "garden of Eden" can be encountered but cannot be sought. It is, of course, a matter of great happiness to be able to apply one's wisdom to the truly noble career of the collective. Otherwise, do not disturb oneself, do not disturb others. If one can really work, then he should work hard; if one cannot work fully for a variety of reasons, he should also try his best to do a good job and live a good life after understanding the world, and focuses on truly good things.

\subsection{Strengthening construction on legality and institutions}

At present, countries including the United States, Canada, Sweden, France, Germany and others have been involved in the management and control of workplace violence related to workplace bullying in the field of the mental harm, damage to employment relationships, occupational discrimination etc. China should adopt its rational thought and practice to build a more perfect legal system for school management, for example, relevant legal provisions to prevent workplace bullying may be added to laws such as the State's Labour Contract Law and the Compulsory Education Act, then to maximize prior prevention and relief afterwards of workplace bullying (Xiao Yongping, 2014 ). Finally, they should realize the organic unity of rule by virtue and by law.

In the process of building a people-oriented school management system, we also need to realize that there are some significant situation differences between China and the Western society in terms of cultural traditions, historical background, social and educational system etc, and it tells us that China should seek a teaching practice and a school management system that is different from the Western society. At the same time as learning from Western society, China should also seek the development of the contemporary school from its long traditional culture and history. Only in this way can we realize the harmonious development of individual, education and society in an environment where education bullying and coercion are minimized.

\section{Acknowledgments}

This research was financially supported by the School level scientific research platform project of Sichuan Special Education Development Research Center (item number: SCTJ2019-06). 


\section{References}

Bao, Xianzhi. (2014). A study of Culture in Workplace Based on the Pragmatic Politeness Principles of Gu Yueguo. Overseas English, (10).

Clock, K., \& Goldsmith, J. (2004). The End of Management and the Rise of Organizational Democracy. San Francisco: Jossey-Bass. A Willey Comp.

Coyne, I., Seigne, E., \& Randall, P. (2000). Predicting workplace victim's status from personality. European Journal of Work and Organizational Psychology, 9(3).

Dictionary Editing Room, Institute of language, Chinese Academy of Social Sciences. (2012). Modern Chinese Dictionary (6 $6^{\text {th }}$ Edition). Beijing: Business Press.

Du Hengbo, Zhu Qianlin, Xu Yanfeng. (2016). The Effect of Workplace Bullying on Knowledge Sharing Intention of Researchers. Chinese soft science, (2).

Einarsen S., Raknes B., I. (1997). Harassment in the workplace and the victimization of men. Violence and Victims, 12(3): 247-63.

Einarsen S. (2005). The nature causes and consequences of bullying at work: the Norwegian experience. Perspectives interdisciplinaires sur le travail et la santé, 7(3). http://journals.openedition. org/pistes/3156. DOI: 10.4000/pistes.3156.

Feng, Hui. (2010). The Impact of the Inertial Factors in Traditional Chinese Culture on the Construction of Government of Law. Academic Exploration, (2).

Feng, Weilin. (2016). The Influence of Workplace Bullying Behavior on Employee's Voice Behavior: The Moderating Effects of Emotional Intelligence. Chongqing: Southwest University of Political Science and Law.

Fu, Meiyun, Ma, Huawei, \& Le Guoan. (2014). Development of Questionnaire on Mental Health Service Providers' Core Competencies. Journal of Southwest University (Social Sciences Edition), (3).

Gu Mingyuan. (2004). The cultural basis of Chinese education. Taiyuan: Shanxi Education Press.

Guo Jing, et al. (2015). Bullying in Workplace in China: An Explorative Study. Chinese Journal of Clinical Psychology, (2).

Chen, Shiting. (2015). The Headmaster of Humanity Management is very attractive. Chinese Journal of Education, (6).

Chen, Weina. (2009). A Review of the Research on bullying in the working Environment. Commercial age, (25).

Ji, Yantin, \& Shi, Changjun. (2017). The present situation and Prevention Strategy of bullying in Campus. Education and Teaching Forum, (11).

Jiang, Jiang, Dong, Jiao, \& Wang, Rong. (2012). Workplace bullying, employee's depression and job satisfaction: Moderating effect of coping strategies. Chinese Mental Health Journal, (8).

Jin, Binghua et al. (2001). Great Dictionary of philosophy (revised). Shanghai: Shanghai Dictionary Press.

Liang, Jing. (2017). Looking at the Chinese Workplace Culture from the Perspective of kinship appellation in Chinese. Journal of Chengdu University (Social Sciences), (3).

Liang, Yuhua, Zhang Xiangsheng. (2016). An empirical analysis on the management style of preschool girl teachers based on job demand. Educational Theory and Practice, (16).

Namie, G., \& Namie, R. (1999). Bully Proof Yourself at work: Personal Strategies to Stop the Hurt from Harassment. Work Doctor.

Nie, Guanghui, Li, Yongxing, \&Tang, Zhenghua. (2011). A Study on the Relationship among Workplace Bullying, Affective Commitment and Intention to Leave. Chinese Journal of Clinical Psychology, (1).

Power, J., Brotheridge, L., Blenkinsopp J, et al. Acceptability of workplace bullying: a comparative study on six continents. Journal of Business Research, (3). 
Ren, Huiyuan. (2019). South Korea implements "workplace bullying prohibition law" how to solve Chinese workplace bullying? Chinese and foreign management, 9.

Samnani, A. K. \& Singh, P. (2016). Workplace Bullying: Considering the Interaction Between Individual and Work Environment. Journal of Business Ethics.

Sheng, Shangwu, Yuanyue. (2012). The Contemporary Value and Defects of Chinese Traditional Culture. Science, Economy, Society, (4).

Silv, Wen Ruoyu, ed. (2015). The Analects, the Doctrine of the Mean \& the Great Learning. Beijing: China Overseas Publishing House.

Tan, Lijun. (2017). Strategies and Enlightenment of developed countries to deal with cyber bullying. Journal of World Education, (4).

Wang, Hong. (2014). Impacts of Bullying at work on work Attitude of Knowledge Workers. Shenyang: Northeastern University.

Wang Kunqing, Yue Wei. (2011). A concise course in philosophy of education. Wuhan: Huazhong normal University Press.

Wang Xiaochun. (2011). Create a non-coercive classroom atmosphere. Henan Education (1).

Xiao Yonping, Peng Shuo. (2014). The experience of overseas legislation of bullying in the workplace and its reference. Journal of Wuhan University (Social Sciences Edition), (3).

Yang, Lijun. (2004). The Negative Influence of Traditional Chinese Culture on Creation Education. Teacher Education Research, (2).

Yu, Luling. (2014). A Review of the Research on Bullying Behavior in the Workplace. Chinese \& Foreign Entrepreneurs, (9).

Zhang, Ying. (2012). A study on the management style of female managers in universities. Master thesis, Shanghai: Shanghai normal University.

Zhao, Fang. (2015). Anti-net bullying: British teachers "straighten up their waist boards". Niaoning education, (3).

Zhao, Pengjuan. (2015). Workplace bullying of shortage subject teachers in primary and secondary schools. Journal of Guizhou Normal University (Natural Sciences) (1).

Zhao Tingting. (2018). The present situation causes and Prevention of bullying in Campus in our country. Contemporary Youth Research, (11).

Zhou Hongjun, Liu Haiming, Wang Yunhao. (2019). Concept, cause, governance policy: a threedimensional structure of Campus bullying Research in China. Educational science research, (7).

\section{Contact:}

Xu Bo

Faculty of Special Education, Leshan Normal University,

Binhe Road 778,

Shizhong district, Leshan City,

Sichuan Province, China

E-mail: xianqingxuzhang@qq.com

Mgr. Xu Bo is a full-time teacher in the Faculty of Special Education at Leshan Normal University. He has long been engaged in teaching and scientific research on basic theories of special education curriculum and teaching, teacher education in special education, critical thinking and so on. 